\title{
Temporal variation in the sediment permeability of an intertidal sandflat
}

\author{
E. Zetsche ${ }^{1,2,4, *}$, D. M. Paterson ${ }^{3}$, D. G. Lumsdon ${ }^{2}$, U. Witte ${ }^{1}$ \\ ${ }^{1}$ Oceanlab, University of Aberdeen, Newburgh AB41 6AA, UK \\ ${ }^{2}$ The Macaulay Land Use Research Institute, Craigiebuckler, Aberdeen AB15 8QH, UK \\ ${ }^{3}$ Sediment Ecology Research Group, Scottish Oceans Institute, University of St Andrews, St Andrews KY16 8LB, UK
}

${ }^{4}$ Present address: Department of Analytical and Environmental Chemistry, Vrije Universiteit Brussel, Brussels 1050, Belgium

\begin{abstract}
Rapid organic matter turnover is driven by advective transport processes in sandy permeable sediments, allowing them to act as biocatalytic filters. This filtering capacity is largely defined by the permeability of the sediment, which describes the flow of water through a porous medium. However, little is known about the temporal variability of sandflat permeability under natural conditions. Therefore, the changes in sediment permeability in an intertidal sandflat were measured over a year. The results demonstrated temporal variation in permeability related to the sediment water content and concentration of extracellular polymeric substances (EPS) in the pore space. The refractory bound fraction of EPS was one of the main contributors to this variation. Proteins associated with the bound EPS fraction appeared to covary with the effect of EPS on permeability. Levels of EPS proteins were as high (415 to $2170 \mu^{-1} \mathrm{~g}^{-1}$ bovine serum albumin equivalents) as carbohydrate levels (560 to $1400 \mathrm{\mu g} \mathrm{g} \mathrm{g}^{-1} \mathrm{D}$-glucose equivalents) in this sediment. Elevated levels of EPS were observed in the summer corresponding to low permeability, which also corresponded with microphytobenthic blooms and resulting production of exudates. A powerful storm event during the experiment with associated wind-generated waves resulted in a reworking of the sediment. This cleared pore spaces, resuspended material and reduced sediment compaction, effecting an overall change in permeability from $3.6 \times 10^{-11}$ to $4.8 \times 10^{-11} \mathrm{~m}^{2}$. The hypotheses that sandy sediment permeability varies with time and is influenced by EPS production were supported, and the effect of an episodic storm event was recorded.
\end{abstract}

KEY WORDS: Sediment permeability - Intertidal sand - Extracellular polymeric substances · Sediment properties

Resale or republication not permitted without written consent of the publisher

\section{INTRODUCTION}

Permeability is the capacity of a porous medium to transmit fluid and is one of the key factors defining the filtering capacity of marine sands (Huettel \& Gust 1992, Boudreau et al. 2001, D'Andrea et al. 2002). In addition, the exchange capacity supported by advective transport processes in permeable non-cohesive sediments supports rapid remineralisation of organic material (Glud 2008). Considering that more than $70 \%$ of the continental shelf is covered by sands (Emery 1968), sediment permeability is an important factor influencing the filtering and cycling of organic matter on the shelf system. Sediment permeability has been estimated for large areas of seabed, predominantly via empirical relationships between sediment grain size and permeability (Bear 1988, Wilson et al. 2008). These relationships have usually been determined by laboratory measurements of characterised sediments. Direct measurements of permeability can be made using a permeameter but these measurements are not routinely carried out or reported. The permeability of sands typically ranges between $10^{-12}$ and $10^{-10} \mathrm{~m}^{2}$ and is controlled by pore 
space characteristics and the tortuosity of fluid flow paths. These variables depend on the physical characteristics of the bed, such as sediment fabric, grain size distribution, shape, particle sorting and porosity (Spinelli et al. 2004), as well as the viscosity and density of the pore fluid (Klute \& Dirksen 1986).

In addition to physical parameters, biological processes mediate sediment properties (Aspden et al. 2004) including permeability. For example, bioturbation alters the distribution of particles, influencing the sorting and packing of grains, and this may either enhance or reduce permeability (Waldbusser \& Marinelli 2009). Infaunal feeding behaviour can also work in both ways, maintaining permeability where fine material is consolidated via defecation and pelletisation (Volkenborn et al. 2007), but also reducing permeability through the blocking of interstitial spaces by the accumulation of faecal pellets (Brunke \& Gonser 1997). Advective processes can transport particulates several $\mathrm{cm}$ into the sediment (Huettel \& Rusch 2000, Huettel et al. 2007). Subsequent physical clogging of sediment is known to reduce permeability (Rehg et al. 2005, Volkenborn et al. 2007). Even small amounts of fine material can have a significant effect: Forster et al. (2003) found permeability to be reduced by a factor of 0.6 from $\sim 5 \times 10^{-12}$ to $\sim 3 \times$ $10^{-12} \mathrm{~m}^{2}$ after the deposition of a thin layer of fine material (particles $<106 \mu \mathrm{m}$ ) in one of very few studies investigating such effects in natural marine sediment cores. Another clogging mechanism, 'bioclogging', also occurs via the transport of allochthonous particulate organic material, such as phytodetritus (Underwood et al. 1995, Huettel et al. 2007) and mucilage deposition (Glud et al. 2008).

Bioclogging primarily denotes the build-up of microbial biomass and related products such as extracellular polymeric substances (EPS). EPS is a generic descriptor of a highly variable matrix of organic compounds such as carbohydrates and proteins, but also lipids, nucleic acids and other biopolymers, and its local composition is dependent on the source of polymer, turnover rates, local physico-chemical conditions and the physiological status of the producers (Decho 1990, Underwood \& Paterson 2003). The distribution of EPS is also determined by sediment transport processes (Grant et al. 1986), and EPS composition and extent is, therefore, highly variable throughout the year. EPS predominantly arises from the presence of microphytobenthos (MPB; cyanobacteria, diatoms and other eukaryotic algal groups) and heterotrophic bacteria, leading to reductions in sediment permeability as the sediment pore spaces effectively become blocked (Pilditch \& Miller 2006, Thull- ner 2010). The ecological importance of EPS is manifold, ranging from adhesion, cell locomotion (diatoms), protection from desiccation, protection from toxins, a food resource and a means of removing excess photosynthetic energy (Underwood \& Paterson 1993, Stal 2010). EPS has been acknowledged to contribute to sediment stability for both marine and fresh water cohesive sediments (Aspden et al. 2004, Gerbersdorf et al. 2009a,b, Stal 2010), and the effects of bioclogging have been extensively investigated for saturated porous media in the laboratory and in flow cell experiments (see Thullner 2010). However, evidence of this biologically mediated effect occurring in natural sandy sediments is limited (e.g. Grant et al. 1986, Meadows \& Meadows 1991, Glud et al. 2008).

Biological and physical sediment characteristics fluctuate as a result of tides, currents and weather patterns. Different bed sediment transport regimes can lead to different effects of fine sediments on hyporheic exchange (Rehg et al. 2005). Episodic events, particularly during strong tides or storms, increase sediment resuspension and may 're-set' sediment permeability by removal of fine particulates and biogenic substances such as EPS. Such resuspension events are important for maintaining the high filtering capacity of sandy sediments, and future impending impacts of changed weather patterns associated with climate change, e.g. more frequent or more intense storm events (Easterling et al. 2000) will thus potentially impact the ecosystem functioning of these sands.

Sediments exhibit spatial heterogeneity in their permeability as a result of variability in relevant properties (Forster et al. 2003, Rocha et al. 2005), and it has been speculated that permeability is also likely to vary temporally, but to our knowledge no field data has been published to confirm this. This study therefore aims to address the following 2 hypotheses: (H1) Temporal variation of permeability is driven by seasonal trends of biological processes, such as accumulation of organic material in summer and by hydrodynamic forces that rework and unclog sediment pore space in winter; and (H2) extracellular polymeric substances can mediate permeability in non-cohesive sediments. For this purpose, an intertidal estuarine sandflat in the Ythan Estuary was investigated biweekly over an annual cycle. This was chosen due to its proximity to the laboratory, enabling close observations of the study site and the possibility of sampling immediately after, for example, an unusually strong wind event. The properties influencing permeability for an intertidal setting were identified and examined as predictors of sediment permeability. 


\section{MATERIALS AND METHODS}

\section{Study site}

This study was conducted on a sandflat in the Ythan Estuary, North-East Scotland $\left(57^{\circ} 20^{\prime} 30^{\prime \prime} \mathrm{N}\right.$, $\left.01^{\circ} 57^{\prime} 30^{\prime \prime} \mathrm{W}\right)$. The Ythan catchment is located about $20 \mathrm{~km}$ north of Aberdeen and encompasses $\sim 685 \mathrm{~km}^{2}$ (Fig. 1). The tidal influence extends for $\sim 10 \mathrm{~km}$ from the mouth at the North Sea to the town of Ellon and the Ythan has generally been described as a wellmixed estuary (Leach 1971). The estuary's intertidal area is estimated at $1.85 \mathrm{~km}^{2}$ (Leach 1971) with flushing time reported from 1.15 tidal cycles (Leach 1971) to 5-12 d (Balls 1994). The selected study site is located in the middle reaches of the Ythan Estuary in close proximity to the laboratory. At low tide the sandflat is generally exposed, with 1 to $2 \mathrm{~m}$ of water column being present at high tide, depending on weather and tidal conditions. Three stations, $\sim 40 \mathrm{~m}$ apart, and at the same tidal level were marked with poles. All samples were taken randomly in a $2 \mathrm{~m}$ radius surrounding each of these fixed positions and treated as replicates. Samples were taken twice a
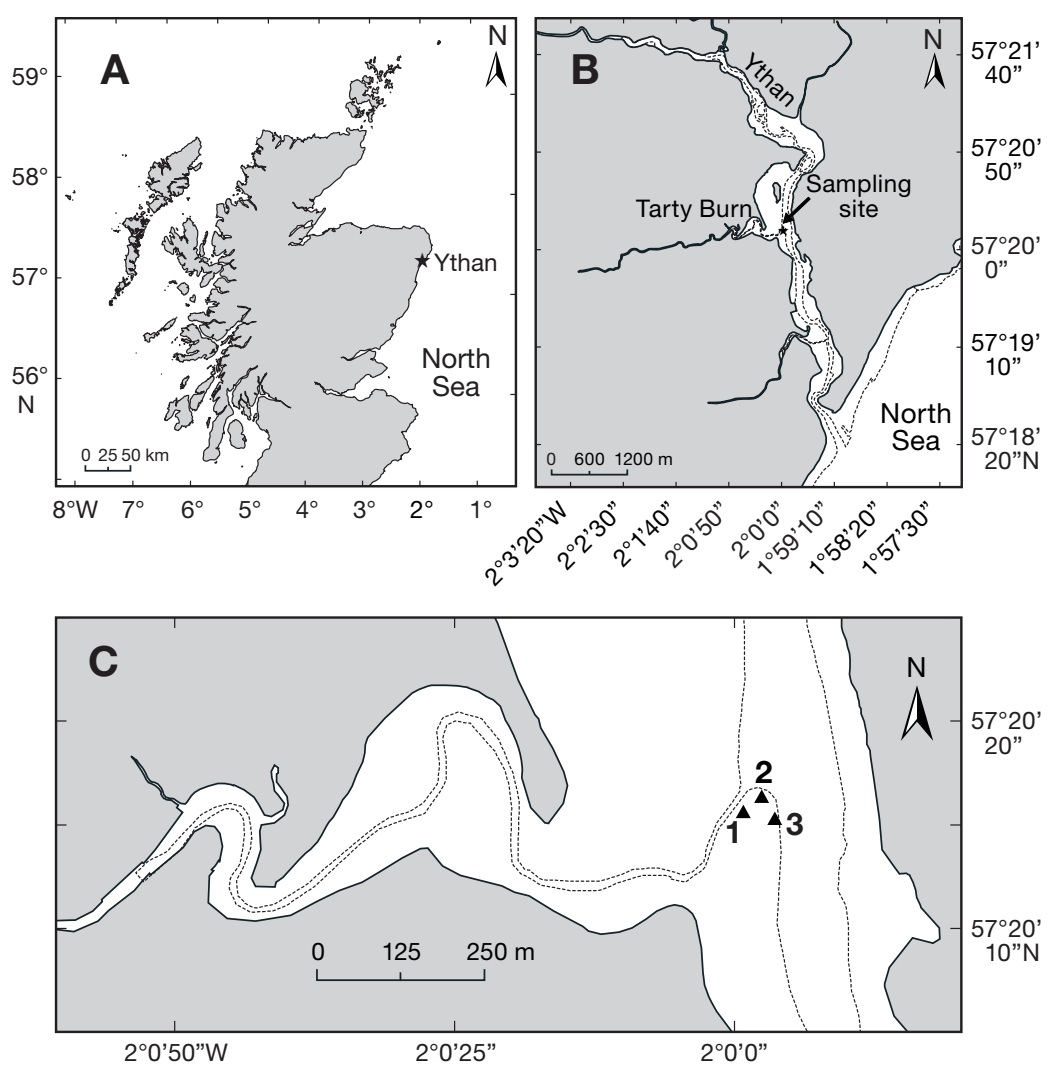

Fig. 1. (A,B) Ythan Estuary, Scotland (UK). (C) The intertidal study site with 3 fixed sampling stations (1,2 and 3) month over the total period of 1 yr between May 2007 and May 2008, which allowed seasonal changes to be investigated. However, a long winter period prevails in the Scottish climate (Harrison et al. 1999), and the boundaries for the 4 seasons have therefore been adapted to accommodate the shifted seasonality. Based on the analysis of temperature and light data collected with data loggers (Onset $\mathrm{HOBO}^{\circledR}$ Pendant Temp/Light Data Logger) at the study site, spring extends from the middle of April until the end of June, summer is from July to mid-September, autumn from mid-September to mid-November with the long winter period from mid-November to mid-April following this.

\section{Core sampling}

Acrylic tubing with an inner diameter of $3.6 \mathrm{~cm}$ was used for coring to a sampling depth of $\sim 15$ to $20 \mathrm{~cm}$. One core was collected from each of the 3 sampling stations for measurements of permeability $\sim 3$ to $4 \mathrm{~h}$ after high tide. Sampling was timed to ensure that an overlying water layer was still present at each station. Cores for measurements of all other sediment properties were taken at low tide. One core per station was obtained for measurements of water content and grain size, and a further core per station was taken for chlorophyll a (chl a) determination. Two extra cores were taken from 2 of the sampling stations as part of another experiment and used to establish whether significant heterogeneity existed at the scale of the $2 \mathrm{~m}$ radius. No significant spatial heterogeneity was found at this scale (data not shown) and hence, at the sampling stations where 2 cores had been taken, measured values were averaged to give 1 value per position for each of the 3 sampling stations per sampling date $(24$ sampling dates), resulting in a total of 72 data points. One core per sampling station was taken at low tide for measurements of EPS.

\section{Sediment permeability}

Permeability was determined using a constant head permeameter (Klute \& Dirksen 1986). A constant head of 
water ( $h=$ pressure head) was applied to each of the 5 collected cores of $15 \mathrm{~cm}$ length $(L)$ and with a surface area of $10.18 \mathrm{~cm}^{2}(A)$. The volume of water flow $(V)$ collected over a given time period $(t)$ was then measured to give hydraulic conductivity $(K)$ where:

$$
K=(V \times L) /(h \times A \times t)
$$

Permeability $\left(k\right.$ in $\left.\mathrm{m}^{2}\right)$ was calculated by:

$$
k=K \times m / d \times g
$$

where $m=$ porewater viscosity $\left(\mathrm{g} \mathrm{m}^{-1} \mathrm{~s}^{-1}\right), d=$ density of the water $\left(\mathrm{g} \mathrm{m}^{-3}\right)$ and gravity $(g)=9.81\left(\mathrm{~m} \mathrm{~s}^{-2}\right)$. Triplicate measurements of 4 different hydrostatic pressures (12 measures), ranging from 9 to $25 \mathrm{~cm}$ of water column, were combined to obtain robust results of $K$ per core. As described above, results from the replicate cores were combined to give a single (average) value for each of the 3 stations. The lower $10 \mathrm{~cm}$ of the cores were then removed and permeability for the remaining top $5 \mathrm{~cm}$ sections determined in the same way. No attempt was made to further resolve vertical or horizontal gradients in permeability since this is not possible with the methodology used.

\section{Extraction and determination of EPS}

From each core collected for EPS measurements, the upper $5 \mathrm{~cm}$ were extruded in $1 \mathrm{~cm}$ sections. Sections were air-dried and frozen until needed for the analysis of EPS according to Gerbersdorf et al. (2008b). Colloidal (water-extractable) EPS was obtained by extracting $120 \mathrm{mg}$ of sediment from each core section in $1.6 \mathrm{ml}$ of distilled water in a $2 \mathrm{ml}$ Eppendorf vial. The vials were vortexed and then continuously rotated at room temperature for $90 \mathrm{~min}$ at a fixed speed of $50 \mathrm{rpm}$ (Denley Spiramix 5; Denley Instruments). Vials were then centrifuged for $10 \mathrm{~min}$ at $16060 \times g$ (Biofuge pico Centrifuge, Heraeus, Rotor 7500 3325) and the supernatant used for the analysis of carbohydrates and proteins. The remaining sediment pellets were further extracted for the bound (resin-extractable) EPS fraction. For this, $1.6 \mathrm{ml}$ distilled water and $100 \mathrm{~g} \mathrm{~g}^{-1}$ volatile solids prewashed (with phosphate-buffered saline, Gerbersdorf et al. 2008a) cation exchange resin (CER, Dowex ${ }^{\circledR}$ Marathon ${ }^{\circledR}$ C sodium form, Sigma Aldrich) were added to each of the vials containing the pellets. Vials were then continuously rotated for $12 \mathrm{~h}$ at room temperature and centrifuged for $10 \mathrm{~min}$, and the resultant supernatant was used for the analysis of carbohydrates and proteins. In this way, both the col- loidal and bound EPS fractions were obtained. For both EPS fractions, triplicate measurements for each core section were determined for spectrophotometric determination of carbohydrates and proteins (Cecil CE 3021 Spectrophotometer, Cecil Instruments) using the Dubois assay and a modified Lowry procedure, respectively (Gerbersdorf et al. 2008b). D-glucose and bovine serum albumin (BSA) were used as standards for carbohydrate and protein analyses respectively, and results are given in $\mu \mathrm{g} \mathrm{g}^{-1}$ equivalents. The various EPS components analysed will be hereafter referred to as colloidal and bound fractions, consisting of $\mathrm{CCH}$ (colloidal carbohydrates) and $\mathrm{CP}$ (colloidal proteins), and $\mathrm{BCH}$ (bound carbohydrates) and BP (bound proteins), respectively.

\section{Sediment characteristics}

Cores for sedimentological analysis were extruded in $1 \mathrm{~cm}$ intervals to $15 \mathrm{~cm}$ depth. Water content was determined from weight loss upon drying at $60^{\circ} \mathrm{C}$ for $24 \mathrm{~h}$. Sediment from all 5 cores from each of the respective slices was pooled for measurements of grain size and determined values used for all 3 stations. Grain size was analysed with a laser particle size analyser (Mastersizer Hydro 2000 G); median grain size, sorting coefficients and \% fines $(<63 \mu \mathrm{m})$ were calculated.

\section{Abundance of macrofauna}

Two large sediment cores $(25 \mathrm{~cm}$ core internal diameter, surface area $0.045 \mathrm{~m}^{2}$, core depth $\sim 10 \mathrm{~cm}$ ) were taken from each station as part of another experiment (E. Zetsche et al. unpubl.) and macrofauna were obtained via retention of organisms on a $500 \mu \mathrm{m}$ sieve. Abundances were determined for the top $1 \mathrm{~cm}$ layer, whilst for one third of the years' samples, analysis of deeper sections (to $5 \mathrm{~cm}$ sediment depth) was also undertaken. Initial analysis of the deeper layer to $10 \mathrm{~cm}$ depth revealed a distinct reduction in organism numbers of $>2$ orders of magnitude (data not shown) for this layer; no further analysis of this deeper layer was consequently undertaken. All samples for the determination of macrofaunal abundance were first preserved in $4 \%$ Rose Bengalstained borax-buffered formalin and then sorted and picked to give total abundances for each core. Counts from the 2 cores of each station were then averaged to provide 1 value per sampling station to compare against the other variables. 


\section{Cryosampling}

The cryolander technique (Wiltshire et al. 1997) was applied in situ on 4 occasions, approximately every $3 \mathrm{mo}$, to obtain a qualitative impression of sediment pore space characteristics over the $1 \mathrm{yr}$ period. Briefly, cryolanding involves the freezing of sediment with liquid nitrogen vapour to obtain intact pore space characteristics to several $\mathrm{cm}$ depth without measurable distortion. Frozen sediment samples were sheared to obtain fracture faces, which were examined by low-temperature scanning electron microscopy (LTSEM, after Paterson 1995) to determine void space.

\section{Wind measurements}

Measurements of wind speed were obtained from the nearest MIDAS Land Surface Stations at Dyce (Station 161) and Peterhead Harbour (Station 170), 20 and 25 (respectively) km away, available courtesy of the British Atmospheric Data Centre (http:// badc.nerc.ac.uk/data/ukmo-midas). The hourly data was combined and processed to obtain mean wind speed $\left(\mathrm{m} \mathrm{s}^{-1}\right)$ per day for the sampling period.

\section{Statistical analyses}

Differences among the seasons of the yr 2007 and 2008 (spring 07, summer, autumn, winter and spring 08) and other between-group comparisons were statistically analysed for the various measured properties (sediment permeability, median grain size, \% fine fraction, water content, and total bound and colloidal fractions of EPS, as well as wind speed). Most data sets did not meet the requirements of normality or homogeneity of variance necessary for parametric analysis. Subsequently, the non-parametric Kruskal-Wallis $H$-Test (1-way analysis of variance on ranks) for between-group analysis was applied. Analysis was undertaken using SigmaStat ${ }^{\circledR} 4$ incorporated into SigmaPlot ${ }^{\circledR} 11.0$ (Systat Software) with a level of significance of $\mathrm{p}<$ 0.05 .

A statistical modelling approach was used to address whether any of the measured variables (median grain size, sediment sorting, \% fine fraction, water content, macrofauna abundance, and bound and colloidal EPS fractions) were capable of explaining the observed patterns in permeability in the $15 \mathrm{~cm}$ cores. Measurements of the 15 individual slices that comprised a full core were averaged to provide 1 representative measurement for sedimentary properties (grain size, sorting, \% fines and water content). Initially, exploratory techniques were applied to the data points $(n=72)$ to check for outliers and possible issues of collinearity. Collinearity effects between sediment sorting and grain size were avoided by eliminating sediment sorting as a variable. Ensuing preliminary data analysis indicated no further significant collinearity among independent variables. Having 3 sampling stations at 1 study site and repeated measurements over time violates assumptions of independence, which was confirmed by using a formal visualisation tool (the auto-correlation function ACF) able to detect such patterns. Temporal trends of permeability showed non-linear relationships (see Fig. 2). Given these structures in the data and the likely non-parametric nature of some of the independent variable effects, we used a generalised additive model (GAM) framework (Wood 2006, Zuur et al. 2009). However, we found marked heterogeneity of variance in the data (between sites) and therefore we developed a generalised additive mixed model (GAMM), which incorporated compensatory terms for heterogeneity of variance with the GAM framework (Wood 2006). The GAMM approach fitted additive smoothing functions based on the independent variables (median grain size, water content, macrofauna abundance, and bound and colloidal EPS fractions) with sediment permeability as the dependent variable:

Permeability Median Grain Size + Water Content + Macrofaunal Abundance + Fine Fraction + Total Colloidal EPS + Total Bound EPS + s(Time, Sampling Stn 1) + s(Time, Sampling Stn 2) + s(Time, Sampling Stn 3)

where $\mathrm{s}$ is time represented by univariate penalised cubic regression spline smooths. The heterogeneity of variance associated with test site was accounted for by treating 'test site' as a random independent variable within the modelling framework. The GAMM approach could therefore adequately model the inherent problems of the temporal and spatial autocorrelation as well as the demands of a small data set without 'overanalysing' the data. The minimum adequate model was determined through manual backwards stepwise selection, using maximum likelihood ratio tests and 5\% significance levels. The statistical modelling was carried out using the statistical and programming software R v.2.9.0 and the mgcv- and nlme-libraries (Wood 2004, 2008). 


\section{RESULTS}

\section{Sediment permeability}

Seasonal differences were observed in the permeability of the $15 \mathrm{~cm}$ cores $(\mathrm{p}<0.001, H=25.49$, $\mathrm{df}=4)$, with spring 2007 and summer 2007 exhibiting the lowest seasonal medians $\left(2.9\right.$ and $3.0 \times 10^{-11} \mathrm{~m}^{2}$, respectively) and the highest median in the spring months of $2008\left(4.8 \times 10^{-11} \mathrm{~m}^{2}\right)$. Measurements of permeability throughout the year for the $15 \mathrm{~cm}$ cores range between 1.9 and $5.8 \times 10^{-11} \mathrm{~m}^{2}$ (Fig. 2A), and were characteristic of a permeable sediment (Huettel \& Gust 1992) allowing advective transport of pore waters to occur where pressure gradients are large enough to induce transport. Permeability was also determined for the upper $5 \mathrm{~cm}$ sections of the cores ranging between 1.6 and $6.3 \times 10^{-11} \mathrm{~m}^{2}$ (Fig. 2B) and these measurements, although showing much greater variability throughout the year, were strongly correlated with the full $15 \mathrm{~cm}$ cores $\left(\mathrm{r}^{2}=0.63, \mathrm{p}<\right.$ 0.001). The overall mean for the 1 yr period (3.6 \pm $0.8 \times 10^{-11} \mathrm{~m}^{2}$ for the $15 \mathrm{~cm}$ cores) agrees well with known values of permeability for continental shelf sands (Wilson et al. 2008).

\section{EPS fractions}

All 4 fractions of EPS demonstrated temporal variability (Fig. 3A to D). Although non-significant, clear trends were shown among seasons in the total colloidal fractions $(\mathrm{p}=0.065, H=8.86, \mathrm{df}=4)$ compared to the total bound fraction ( $\mathrm{p}=0.30, H=4.91$, $\mathrm{df}=4)$. The sediment content of bound material had an an-
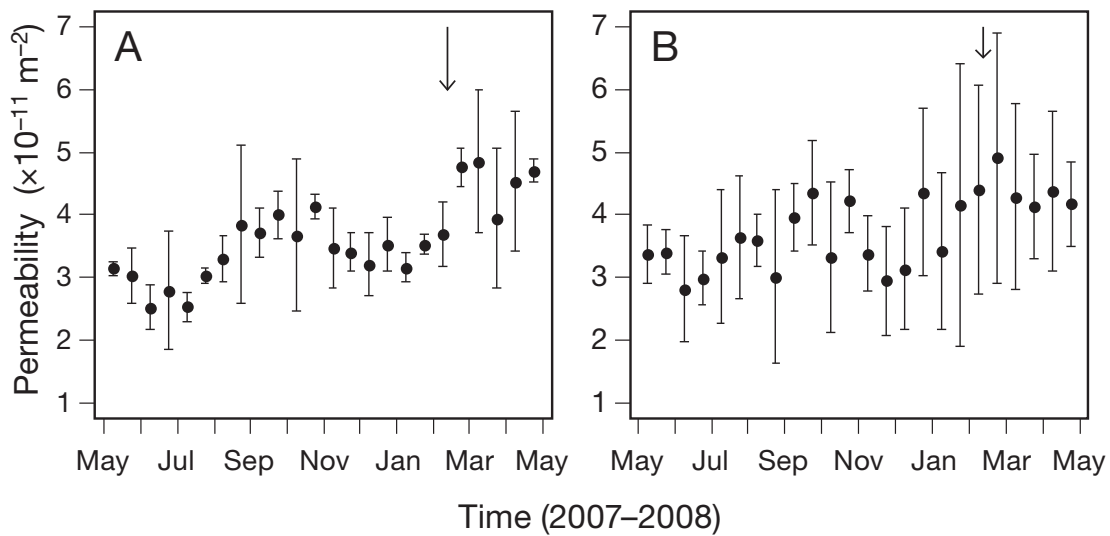

Fig. 2. Permeability (in $\mathrm{m}^{2}$ ) over the 1 yr period (May 2007 to May 2008). Means \pm SD for each sampling occasion. Permeability of cores of (A) $15 \mathrm{~cm}$ and (B) $5 \mathrm{~cm}$ length were measured with a constant head permeameter. Arrow: storm event in the first 2 wk of March 2008 nual range of 450 to $1590 \mathrm{\mu g} \mathrm{g}^{-1}$, which was lower than the colloidal fraction (470 to $2190 \mu^{-1} \mathrm{~g}^{-1}$ ). Proteins, both $\mathrm{CP}$ and $\mathrm{BP}$, were always a more dominant component of the EPS than the carbohydrates, BP having an annual mean of $66 \%$ of the total bound fraction and $\mathrm{CP}$ representing $52 \%$ of the total colloidal fraction. Over the $1 \mathrm{yr}$ sampling period, the ratio of total protein to total carbohydrate concentration was generally $>1$ (annual mean $1.41 \pm 0.32$ ). Differences between the EPS concentrations of the top $1 \mathrm{~cm}$ and at $5 \mathrm{~cm}$ depth for each sampling date (comparing the averages of the 3 measured cores for the respective layers) were similar for all 4 fractions, but generally higher for the colloidal compared to the bound fractions. Vertical depth profiles for $\mathrm{CCH}$ and $\mathrm{CP}$ indicate slight decreases with depth more often throughout the year than $\mathrm{BCH}$ and $\mathrm{BP}$. Interestingly, the difference in the ratios of $\mathrm{CCH}$ to $\mathrm{BCH}$ and $\mathrm{CP}$ to $\mathrm{BP}$ also varied over the year (Fig. 3E,F). This temporal variation reveals alternating periods of higher colloidal fractions and periods of increased bound material. For carbohydrates, overall, $\mathrm{CCH}$ was consistently high enough that the $\mathrm{CCH}: \mathrm{BCH}$ ratio was always higher than $\mathrm{CP}$ :BP values. In contrast, BP exhibited a much stronger influence on yearly changes of the protein ratios.

Meio- and macrofauna, microalgae and bacteria all secrete forms of EPS. In this study, only macrofaunal abundance was examined and showed no correlation to any of the EPS fractions $\left(r^{2}<0.05\right)$. Results from the cryosampling clearly demonstrated low levels of EPS in winter (27 February 2008); the sediment pore space was predominantly filled by water (Fig. 4A), whereas in the summer the sediment was enveloped in organic material (21 August 2007) (Fig. 4B). This was illustrated by LTSEM images obtained from a visible MPB bloom at the study site (Fig. 4C,D), where benthic microalgae and secreted EPS completely fill the pore spaces between individual sand grains. LTSEM reveals that in all seasons the surface topography of grains was smoothed by MPB and EPS (Fig. 4E,F).

\section{Sediment characteristics}

The site represents an area of permeable well-sorted medium sand (median grain size $336 \mu \mathrm{m}$ ) having a fairly uniform water content $(\sim 20 \%)$. Although the sediment variables median 

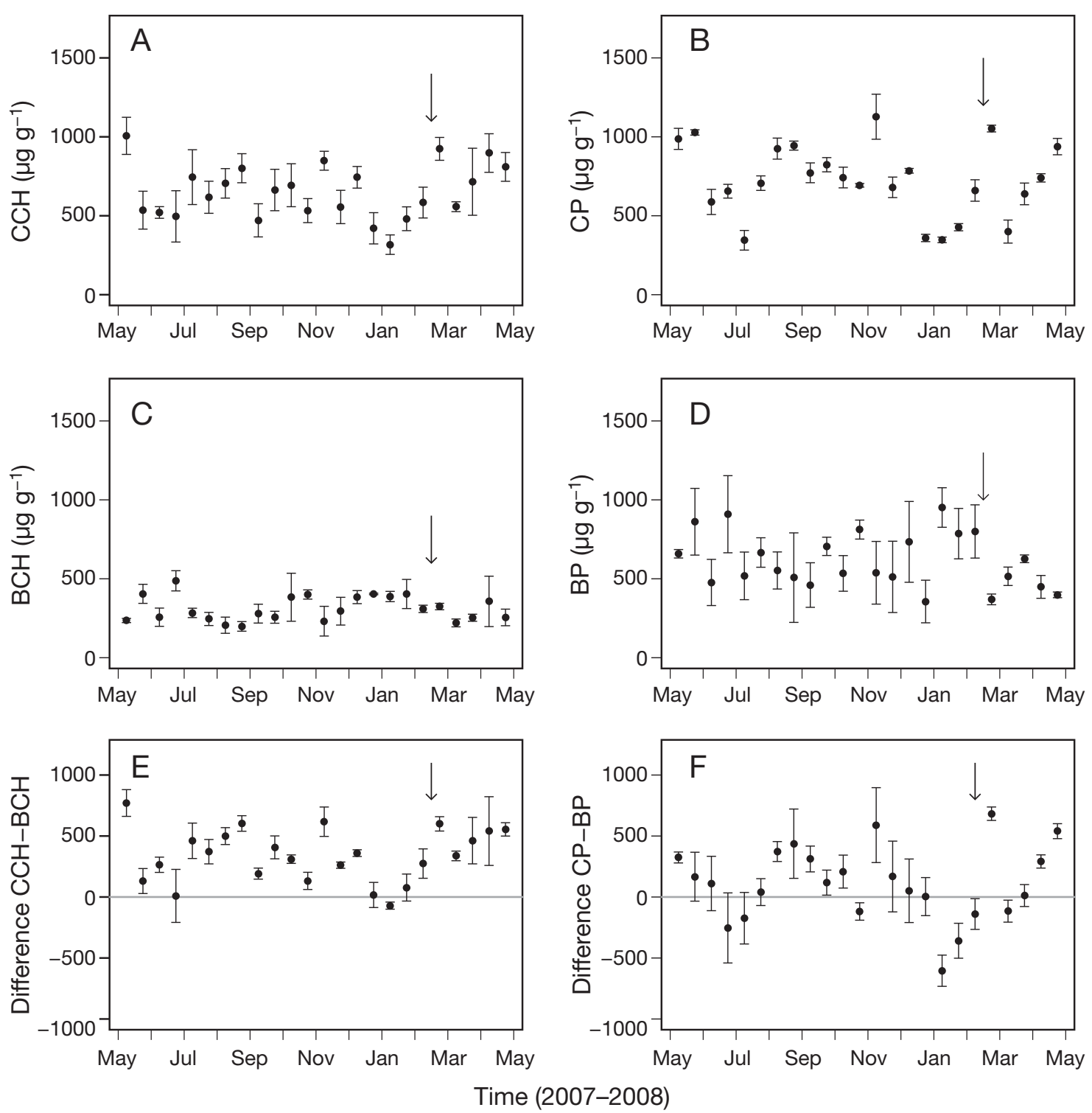

Fig. 3. Different fractions of extracellular polymeric substances (EPS) measured bi-monthly at the 3 sampling stations (means \pm SD): (A) colloidal carbohydrates (CCH), (B) colloidal proteins (CP), (C) bound carbohydrates (BCH) and (D) bound proteins (BP). (E) and (F) show the calculated differences between the colloidal and bound fractions of the carbohydrate and protein pools, respectively. Arrow: storm event in March 2008

grain size, \% fine fraction and \% water content exhibited differences among the seasons, only changes in the water content were significant (Table 1). Vertical depth profiles of the water content of the $15 \mathrm{~cm}$ cores generally revealed a minor reduction in water content with depth (on average $<1 \%$ ) but there were greater differences between the 3 stations over the 1 yr period (Fig. 5). The percentage of fine material $(<63 \mu \mathrm{m})$ was low, averaging $0.2 \%$ for the $15 \mathrm{~cm}$ cores over the $1 \mathrm{yr}$ sampling period. The highest fraction measured was $1.3 \%$ on the 3 December 2007.

\section{Abundance of benthic macrofauna}

Macrofauna collected from the site in the upper sediment layers was generally small in size $(<1 \mathrm{~cm})$ and dominated by oligochaetes, nematodes and harpacticoid copepods. Larger organisms were rarely observed in the cores, for example, the cockle Cerastoderma edule was only present in 6 of the 144 cores sampled, and no evidence of large burrowing structures was observed. Large bioturbators, such as the lugworm Arenicola marina, were rare on the sandflat 

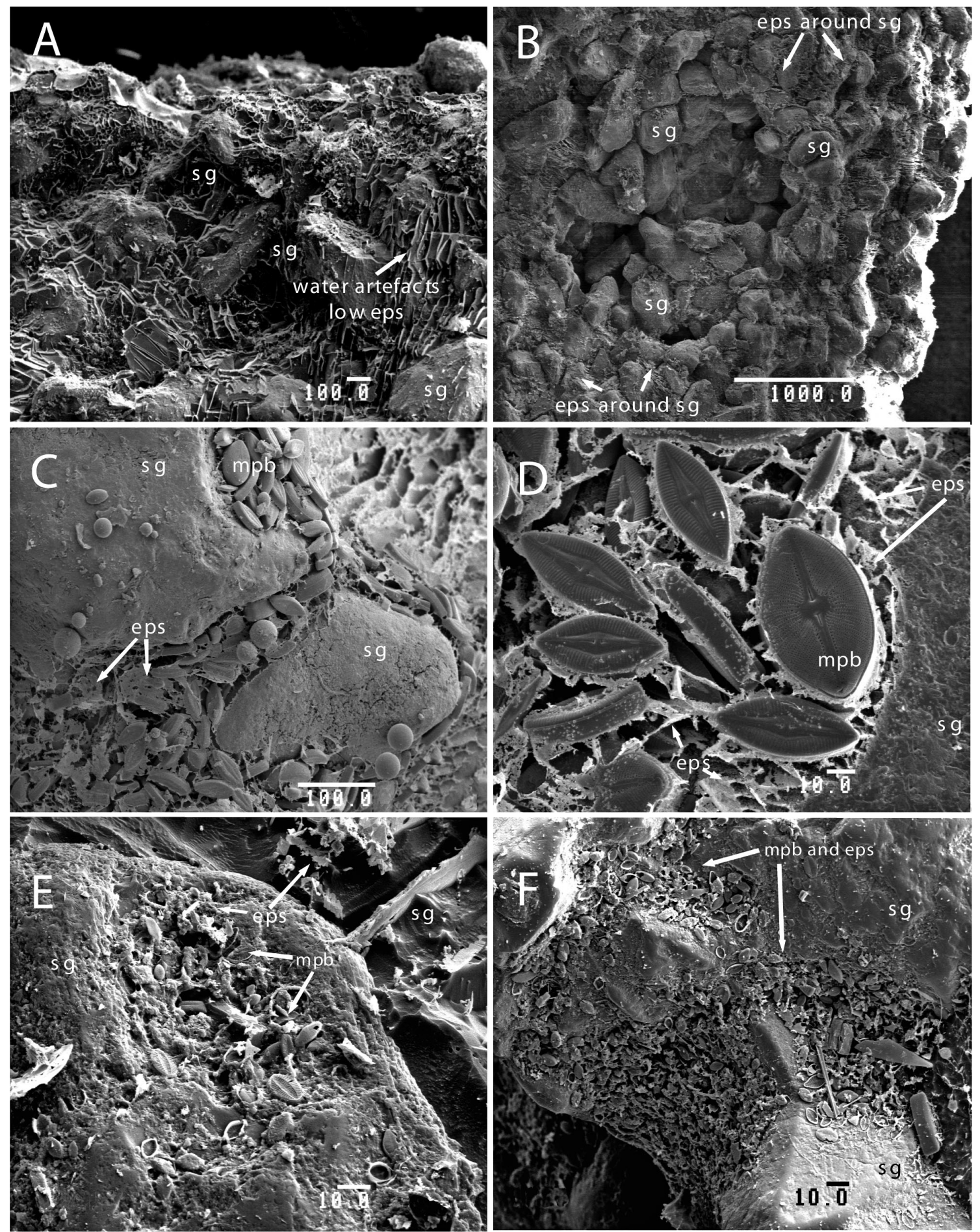

Fig. 4. Low-temperature scanning electron microscope (LTSEM) micrographs of the sediment surface. (A) Fracture-face of the sediment core in winter showing the pore space structure to be waterlogged (top of image: sediment surface, scale bar $=$ $100 \mu \mathrm{m})$. (B) Fracture-face of the sediment core in summer showing grains coated with organic material (right of image: sediment surface, scale bar $=1000 \mu \mathrm{m})$. $(\mathrm{C})$ Surface of a microphytobenthos bloom at the site in summer; pore spaces are clogged with microalgae and extracellular polymeric substances (EPS) (scale bar $=100 \mu \mathrm{m}$ ). (D) Detail of a fracture face. Note the depth of the epipelic diatoms embedded in EPS (right of image: sediment surface, scale bar $=10 \mu \mathrm{m}$ ). (E) Tight association of epipsammic algae and EPS on sand grains shortly before the storm event (27 February 2008) (scale bar $=10 \mu m)$. (F) Epipsammic cells and extruded material change grain surface characteristics, here seen in a fracture face in autumn 2007 (scale bar = $10 \mu \mathrm{m}$ ). 
Table 1. Sedimentary characteristics (median grain size, fine fraction and water content) for the $15 \mathrm{~cm}$ cores, means for each season. Seasonal differences $(\mathrm{df}=4)$ were statistically analysed using non-parametric testing (Kruskal-Wallis $H$-test). Significant $(p<0.05)$ results are indicated in bold

\begin{tabular}{|lcccccrr|}
\hline Parameter & Spring 07 & Summer & Autumn & Winter & Spring 08 & p-value & $H$-statistic \\
\hline Median grain size $(\mu \mathrm{m})$ & 346 & 332 & 334 & 328 & 329 & 0.059 & 9.09 \\
\% Fines $(<63 \mu \mathrm{m})$ & 0.11 & 0.27 & 0.09 & 0.00 & 0.09 & 0.568 & 2.94 \\
Water content $(\%)$ & 20.0 & 19.4 & 19.2 & 19.8 & 20.3 & $\mathbf{0 . 0 0 7}$ & 14.12 \\
\hline
\end{tabular}

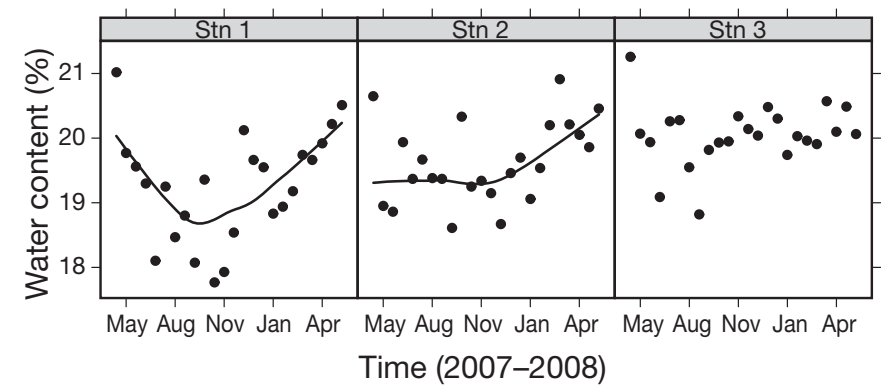

Fig. 5. Water content (\%) at each of the 3 sampling stations (1,2 and 3) over the 1 yr sampling period. The lines on the scatter plots were fitted by weighted least squares

during the sampling period and were never found in any of the $15 \mathrm{~cm}$ deep cores.

\section{Wind measurements}

Mean daily wind speed was highly variable throughout the sampling period (0.6 to $13.1 \mathrm{~m} \mathrm{~s}^{-1}$ ) and showed significant differences among the seasons $(\mathrm{p}<0.03, H=10.80, \mathrm{df}=4)$. The median summer wind speed was distinctly lower $\left(2.4 \mathrm{~m} \mathrm{~s}^{-1}\right)$ compared to all other seasons, where median wind speeds ranged from 4.1 to $5.2 \mathrm{~m} \mathrm{~s}^{-1}$. Calculated seasonal averages showed speeds in winter 2007 to $08>$ autumn $2007>$ spring $2007>$ spring $2008>$ summer 2007. An $\sim 2$ wk long storm event took place at the beginning of March 2008: persistent high winds were observed throughout the period between the sampling occasions on the 27 February 2008 and 13 March 2008. Although the available wind data only approximates conditions for the Ythan, the highest $2 \mathrm{wk}$ average $\left(6.5 \mathrm{~m} \mathrm{~s}^{-1}\right)$ was measured during this storm period (Fig. 6).

\section{Statistical modelling of permeability}

The minimal adequate model using the GAMM approach was established based on the significance of each of the explanatory variables and the lack of any patterns in the model residuals (Zuur et al. 2009). This led to the minimum adequate model which indicated that neither grain size, macrofaunal abundance nor colloidal EPS content contributed to the model, but that the permeability of $15 \mathrm{~cm}$ cores was mainly related to 3 variables: water content + bound EPS + time (as smoothing functions for the 3 stations). The proportion of fine sediment as a fraction of the total sediment was eliminated as a variable prior to the modelling since preliminary analysis revealed that this fraction showed no relationship to sediment permeability. Given the limited number of total data points used in the model, the most parsimonious model was preferred. Fitted values based on the full model are presented (Fig. 7A) and show no residual patterns, thereby validating the model. The minimum adequate model revealed that the content of total bound EPS and sediment water content had a linear relationship with permeability and were both important estimators of sediment permeability (Table 2). At Stns 1 and 3 (Fig. 7B,D), the increase in sediment

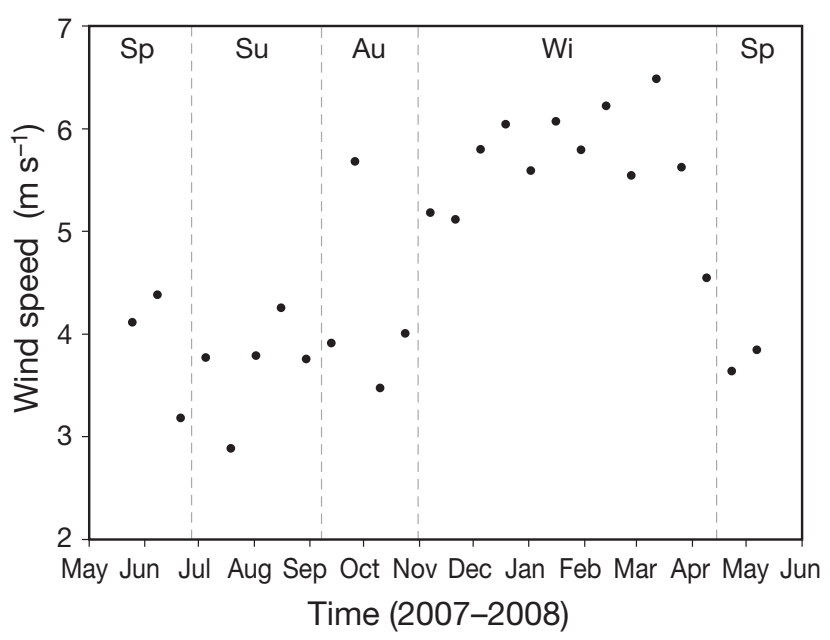

Fig. 6. Wind speeds $\left(\mathrm{m} \mathrm{s}^{-1}\right)$ for $2 \mathrm{wk}$ averages obtained during the sampling period from Peterhead and Dyce to approximate conditions for the Ythan Estuary. Vertical lines demarcate seasonal boundaries $(\mathrm{Sp}=$ spring, $\mathrm{Su}=$ summer, $\mathrm{Au}=$ autumn, $\mathrm{Wi}=$ winter) 

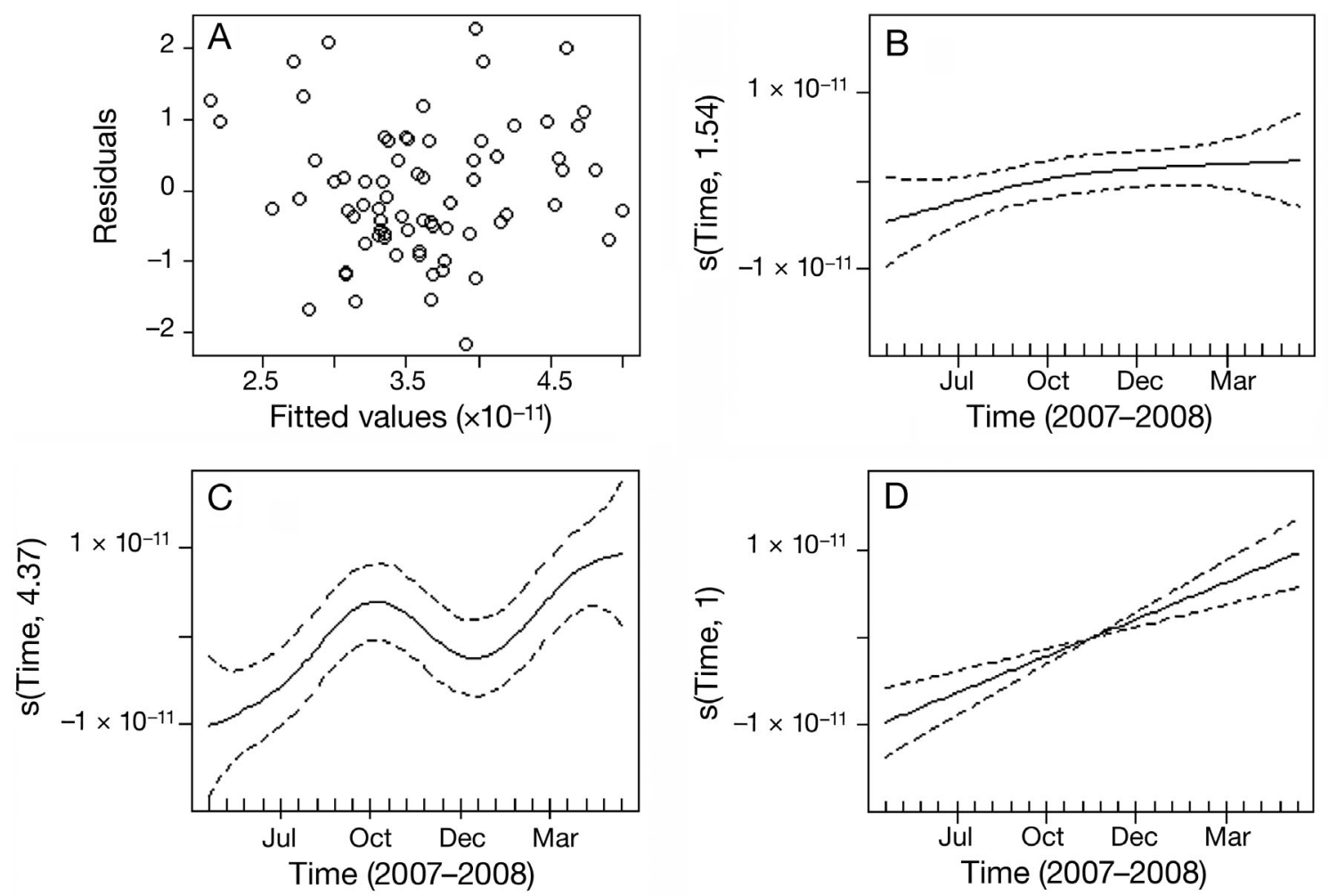

Fig. 7. (A) Validation plot for the minimum adequate generalised additive mixed model (GAMM) with permeability as the dependent variable, showing fitted values against model residuals and indicating the acceptable range in values for the residuals as well as a lack of patterning. Estimated smoothing curves for 3 components of the model are also shown: effect of sampling (B) Stn 1, (C) Stn 2 and (D) Stn 3. Time (mo) is on the $x$-axis, and the $y$-axis indicates the contribution of the smoother to the fitted model values in the form of the partial effects of the sample site, i.e. the contribution of that factor (sample site) when all other significant factors in the model are accounted for. The solid line is the estimated smoother, and the dashed lines indicate the $95 \%$ confidence intervals around this estimate

permeability with time was almost linear with the estimated degrees of freedom (edf) being 1.54 and 1 , respectively. At Stn 2 (Fig. $7 \mathrm{C}$ ) the trend was clearly non-linear (edf $=4.37$ ). Although $\mathrm{r}^{2}$-values are confounded by some uncertainty in GAMM procedures, the minimum adequate model explains $\sim 53 \%$ (adjusted $\mathrm{r}^{2}$ ) of the variation observed in the permeability throughout the year at this study site.

Table 2. Estimated regression metrics for the optimal generalised additive mixed model (GAMM). Of the sediment characteristics measured, total bound extracellular polymeric substances (EPS) and water content drive changes in sediment permeability over time

\begin{tabular}{|lrcrc|}
\hline Variables & $\beta$-coefficient & SE & $F$ & $\mathrm{p}$ \\
\hline Total bound EPS & $-8.31 \times 10^{-12}$ & $2.67 \times 10^{-15}$ & 9.93 & 0.003 \\
Water content & $2.39 \times 10^{-12}$ & $1.04 \times 10^{-12}$ & 5.69 & 0.020 \\
s(Sampling) for Stn 1 & $-6.84 \times 10^{-12}$ & $4.00 \times 10^{-12}$ & 1.60 & 0.185 \\
s(Sampling) for Stn 2 & $-1.62 \times 10^{-11}$ & $0.41 \times 10^{-11}$ & 3.66 & 0.001 \\
s(Sampling) for Stn 3 & $-1.96 \times 10^{-11}$ & $0.39 \times 10^{-11}$ & 24.88 & $<0.0001$ \\
\hline
\end{tabular}

\section{DISCUSSION}

Sediment permeability at the study site varied temporally over a 1 yr period, confirming that temporal heterogeneity in sediment characteristics also needs to be examined, particularly when trying to understand the ecosystem functioning of these permeable sands. In this study, EPS fractions and water content were key contributors to the observed temporal variability in sediment permeability.

\section{Influence of EPS on permeability}

Permeability was lowest in the spring and summer 2007, corresponding to higher EPS concentrations measured during these months, whilst higher permeabilities measured in the colder months corresponded to 
low values of EPS. EPS clogs pores (Probert 1984, de Winder et al. 1999), or leads to greater retention of particles such as diatoms in pores partially filled with EPS (Krembs et al. 2011). Convoluted pores increase tortuosity and decrease permeability, whilst reduced advection and diffusion is experienced as a result of increases in fluid viscosity due to the gelling properties of EPS (Krembs et al. 2011). EPS is an unstructured, amorphous gel-solution matrix (Perkins et al. 2006) and the 2 fractions (colloidal and bound) cannot be distinguished with the LTSEM imagery, especially as LTSEM has to be interpreted with care since artefacts are frequent (Perkins et al. 2006). Despite not being able to distinguish the EPS fractions with the LTSEM, clear differences can be seen in the amount of material present within the sediment matrix among various times of the year (Fig. $4 \mathrm{C}$ to $\mathrm{F}$ ).

The origin of the EPS can not be clearly identified, since it is secreted by algal cells and bacteria, but may also be excreted in copious amounts by other organisms such as meiofauna (e.g. nematodes and harpacticoid copepods), affecting sediment binding (Probert 1984). Greater vertical penetration due to deeper oxidised zones in these permeable sediments also allows much greater movement of these organisms, extending their influence beyond the surface layers (Probert 1984). The content of all EPS components for the present study site were typical for intertidal sediments (e.g. de Winder et al. 1999, Gerbersdorf et al. 2009b). The colloidal fraction was generally the more labile fraction and is known to be rapidly utilised (Middelburg et al. 2000) or washed out upon tidal immersion. The bound fraction is more refractory, being less readily digested (Decho 1990). The colloidal fraction was generally present in greater amounts (Fig. 3), but it is the bound fraction that is implicated in affecting sediment permeability in this study (Table 2). More specifically, the bound proteins were the dominant component impacting sediment permeability. Protein may well increase the density of the EPS, and hence reduce its porosity, by cross-bridging. In activated sludge filtration and membrane fouling studies, it has been shown that it is the protein content of the EPS components which decreases the permeate flux (Mukai et al. 2000, Chang et al. 2002). Protein contributions to sedimentary organic matter can be higher than those of carbohydrates in sandy environments (Incera et al. 2003) and, although proteins have been less well-studied, their role in the substratum stability of sediments may be as important as that of carbohydrates (Gerbersdorf et al. 2008b) or allow carbohydrate polymers to bind more effectively.

\section{Effects of sediment transport and reworking}

Various abiotic factors affect EPS, such as sediment transport which leads to erosion, burial and exposure of depositional sites (Grant et al. 1986). Grant et al. (1986) also emphasised the patchiness of diatom films on a scale of $\mathrm{cm}$ and their relation to ripple structures - the heterogeneity of the films being caused by sediment transport. In sandy sediments where high permeabilities support advective transport processes, EPS is not restricted to the upper $\mathrm{mm}$ of the sediment but can be found at much greater depths at similar concentrations to the surface layer (e.g. $\sim 10 \mathrm{~cm}$, Hedtkamp 2005). This corresponds to the presence of (benthic) algal material as measured by chlorophyll $a$ at these depths (Hedtkamp 2005). At our site, chlorophyll a concentrations between the surface (top $1 \mathrm{~cm}$ slice) and bottom (at $15 \mathrm{~cm}$ depth) only vary by 1 to $2 \mu \mathrm{g} \mathrm{g}^{-1}$ sediment in spring and winter, compared to $\sim 6 \mathrm{~g} \mathrm{~g}^{-1}$ sediment in summer and autumn, indicating more homogeneous vertical distributions in the colder months (E. Zetsche et al. unpubl.). Algal particles are being transported at least several $\mathrm{cm}$ into the sediment at this study site, as found in other studies (e.g. Huettel \& Rusch 2000, D'Andrea et al. 2002, Huettel et al. 2007) as a result of advective transport rather than migration (e.g. diatoms).

Physical advection in the upper $10 \mathrm{~cm}$ of the bed promotes the high permeability of the sandflats studied by D'Andrea et al. (2004), and under more severe storms, depths of activity for sediment layers can be greater (Greenwood \& Hale 1980). Sediment transport was not investigated in this study, but the sediment was significantly reworked during the storm event (authors' pers. obs., Fig. 8). Rehg et al. (2005) found that streams with different bed sediment transport regimes exhibit different clogging impacts of fine sediment on hyporheic exchange. Continuous bed sediment transport or frequent episodic transport events led to accumulation of fine sediment below the active sediment depth rather than in the surface, as found for sediment in streams with only occasional bed sediment transport (Rehg et al. 2005). Huettel \& Rusch (2000) also relate bottom current flow velocity (sediment resuspension and deposition) to permeability and particulate organic matter transport and mineralisation in shelf sediments, highlighting the importance of bed sediment transport processes.

A $2 \mathrm{wk}$ long storm event caused a distinct shift in the observed permeabilities (Fig. 2A, Table 3). Although permeability in the upper $5 \mathrm{~cm}$ of sediment cores did not change significantly before or after the storm, permeability measured for the full $15 \mathrm{~cm}$ core 


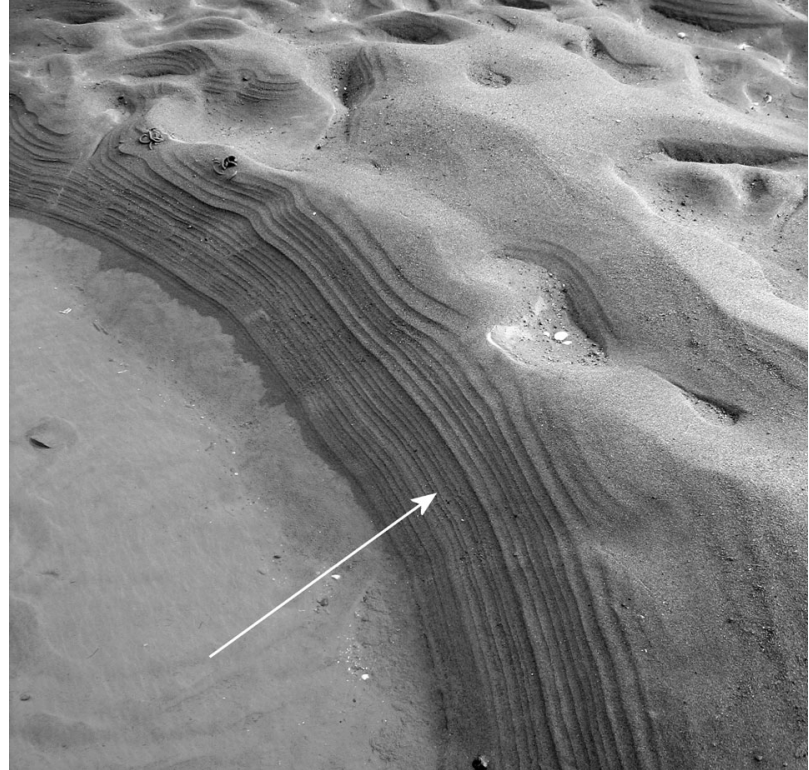

Fig. 8. Depiction of the extensive sediment reworking (layering) that was observed during the sampling on 13 March 2008 as a result of the storm event during the 2 wk prior to this sampling occasion. Each 'layer' is between 1 and $2 \mathrm{~cm}$ in width

did, suggesting that such a major event is needed to re-set sediment permeability at these greater depths. EPS fractions also exhibited distinct shifts in their concentrations from before to after the storm (Table 3), suggesting that the sediment reworking associated with the storm event affected pore spaces, and we suggest that the sediment undergoes cycles of pore clogging and unclogging over time. Faunal disturbance by sediment bioturbation can also contribute to sediment stabilisation as well as destabilisation (Probert 1984, Volkenborn et al. 2007). However, the low faunal abundances and small-sized organisms indicate that sediment movement is likely suppressing

Table 3. Variables (means) taken on the 2 sampling occasions in the month prior to the storm event (February) compared to after (March) in 2008 and their levels of significance. Significant $p$-values $(p<0.05)$ are bold

\begin{tabular}{|lccccc|}
\hline \multirow{2}{*}{ Variable } & \multirow{2}{*}{\begin{tabular}{c} 
Core \\
\cline { 3 - 4 }
\end{tabular}} & $\begin{array}{c}\text { Month } \\
\text { length }(\mathrm{cm})\end{array}$ & Before & After & \\
\hline $\begin{array}{c}\text { Permeability } \\
\left(\times 10^{-11} \mathrm{~m}^{2}\right)\end{array}$ & 5 & 5.28 & 5.133 & 0.699 \\
$\begin{array}{c}\text { Total colloidal pool } \\
\left(\mu \mathrm{g} \mathrm{g}^{-1} \text { equiv. }\right)\end{array}$ & 15 & 3.61 & 4.81 & $\mathbf{0 . 0 0 5}$ \\
$\begin{array}{c}\text { Total bound pool } \\
\left(\mu \mathrm{g} \mathrm{g}^{-1} \text { equiv. }\right)\end{array}$ & 5 & 1061 & 1473 & 0.394 \\
Water content & 5 & 1141 & 699 & $\mathbf{0 . 0 0 2}$ \\
& 15 & 19.64 & 20.17 & 0.098 \\
\hline
\end{tabular}

bioturbation due to mechanical stress (Huettel \& Rusch 2000), making it difficult to identify their role in mediating changes to permeability in the upper $5 \mathrm{~cm}$ layer despite their higher abundance in this layer. On the depth scale of the full $15 \mathrm{~cm}$, the model supports the view that macrofaunal abundance does not greatly influence permeability for this site.

Wind forcing has an impact on the pressure gradients formed in the sediment as well as indirectly on the sediment properties, such as sediment consolidation (Grant et al. 1986, Hedtkamp 2005). Disturbance by waves can influence sediment packing and rewater sediment at depths, increasing permeability, as suggested by the, albeit non-significant, increase in water content from before to after the storm event. Direct measurements at study sites should be included in future studies to gain a better understanding of the wind forcing component.

Generally, where the sediment at the study site was more waterlogged, the permeability was higher. In addition to the daily inundation and emersion cycles, tidal cycles over the year influenced the level of water saturation of the sandflat. Temporal patterns observed in the water content showed greater variability at Stn 1 (Fig. 5) whilst a strong non-linearity over time was observed in sediment permeability at Stn 2 (Fig. 7C), implying that other factors, not identified with our sampling design, were likely to be responsible for this variation. Although non-linearity is not unexpected, finding it in these patterns highlights the need for studying temporal heterogeneity in sediment systems.

Lack of better resolution measurements for grain size and the fine fraction of the sediment also limit conclusions from these variables, despite their potential impact on sediment consolidation, and, directly and indirectly, on sediment permeability. Grain size did not vary significantly over the $1 \mathrm{yr}$ period and therefore did not change sediment permeability. The low measures of \% fines and lack of relationship to measured sediment permeability do not necessarily imply that these values cannot be of significant influence, but this would require further study. Volkenborn et al. (2007) found $1 \%$ fines content to be a critical point above which their study sediment became clogged, showing a clear relationship between \% fines and sediment permeability. As fine particles accumulate, sandy sediments can shift to mudflats (Volkenborn et al. 2007); however, this generally occurs only where wave disturbance or bioturbative activity is low since clays are readily remobilised when bed sediment transport occurs (Rehg et al. 2005). Given the consistent presence of sand ripples 
at the site and the fact that the site has maintained its character as a sandflat over the past decades suggests that settlement of fine particles plays a marginal role here.

This study successfully demonstrated variation in sediment permeability with time for the study site. By regular sampling, we were able to capture temporal heterogeneity and also the influence of an episodic event such as a $2 \mathrm{wk}$ storm, which was found to be important for maintaining the high filtering capacity of these sands. Such large-scale disturbances maintain the ecosystem function of sandy habitats, yet, given the possible effects of climate change (e.g. increasing storm frequencies and intensities), more work is needed to fully understand possible consequences for these habitats. Variation in permeability was mediated through the influence of EPS, providing evidence to support hypothesis 1, and through changes in water content - which was the only sedimentary characteristic to be a main contributory variable to the statistical model explaining the temporal changes in permeability at this site. However, not all the variability could be explained solely by changes in EPS and water content. Increasing the frequency and extent of sampling would be needed to increase the resolution of studies and determine the inherent spatial and temporal scales of permeability variation and how this applies to other intertidal sandflats.

\section{Limitations of empirical estimations}

The importance of grain size for estimating permeability $(k)$ is well-known throughout the extensive hydrogeology literature, generally relating $k$ to the (mean) diameter of the grains (or pore throat diameter) and a dimensionless constant that includes properties such as path tortuosity, particle shape, sorting and porosity (Shepherd 1989), yet it did not become a predictor in our statistical model. Grain size composition strongly determined sediment permeability in work done by Volkenborn et al. (2007), but applications of the empirical relationships to marine sands is generally sparse and of mixed success (see Wilson et al. 2008). Forster et al. (2003) applied the well-known formulations of Krumbein \& Monk (1942) (referred to as KM hereafter) and Carman-Kozemy (Carman 1937, Bear 1988) to vertical permeability measurements in the Baltic Sea. Both relationships overestimated measured permeabilities, with KM being the more successful approach (within a factor of 2.6). Further studies by Rusch et al. (2001) and Janssen et al. (2005) found a similar offset of $3.9 \pm 2.2$ (mean \pm SD) and $2.0 \pm 0.9$ for $\mathrm{KM}$, respectively. Janssen et al. (2005) attributed this overestimation to the lack of consideration of grain size distribution, skewness and kurtosis, and the possible bioclogging of pores. Frequently, transport and flow models in surface water sediments also neglect sediment compaction despite its importance for sediment porosity (Holzbecher 2002). The similar lack of fit with the KM equation, which overestimated the current data by a factor of $1.5 \pm 0.4$, further supports the assertion that other factors, such as EPS impacting the pore space characteristics of the sediment, are important as estimators of sediment permeability.

Acknowledgements. We thank Oceanlab staff and students for their laboratory and fieldwork assistance. Advice in statistical analysis by M. Bulling, A. Douglas and I. Katara are gratefully acknowledged. C. Beattie kindly assisted with the processing of the wind data. We are grateful to I. Davidson for the LTSEM imagery and S. Gerbersdorf for her expert knowledge of analysing EPS. Permission to sample on the Ythan was provided by the Forvie National Nature Reserve, Scottish Natural Heritage. D.M.P. acknowledges the support of the Marine Alliance for Science and Technology for Scotland (MASTS) during this work. E.Z. was funded by a UK PhD grant from ACES (Aberdeen Centre for Environmental Sustainability). We also thank 3 anonymous reviewers for helping to improve the manuscript.

\section{LITERATURE CITED}

Aspden RJ, Vardy S, Paterson DM (2004) Salt marsh microbial ecology: Microbes, benthic mats and sediment movement. In: Fagherazzi S, Marani M, Blum LK (eds) Coastal and estuarine studies, 59: The ecogeomorphology of tidal marshes. AGU, p 115-136

Balls PW (1994) Nutrient inputs to estuaries from nine Scottish east coast rivers: Influence of estuarine processes on inputs to the North Sea. Estuar Coast Shelf Sci 39: 329-352

Bear J (1988) Dynamics of fluids in porous media. Dover, New York

Boudreau B, Huettel M, Forster R, Jahnke A and others (2001) Permeable marine sediments: overturning an old paradigm. Eos Trans AGU 82:133-136

Brunke M, Gonser T (1997) The ecological significance of exchange processes between rivers and groundwater. Freshw Biol 37:1-33

Carman PC (1937) Fluid flow through granular beds. T I Chem Eng-Lond 15: 150

Chang IS, Le Clech P, Jefferson B, Judd S (2002) Membrane fouling in membrane bioreactors for wastewater treatment. J Environ Eng 128:1018-1029

D'Andrea AF, Aller RC, Lopez GR (2002) Organic matter flux and reactivity on a South Carolina sandflat: The impacts of porewater advection and macrobiological structures. Limnol Oceanogr 47:1056-1070

D'Andrea AF, Lopez GR, Aller RC (2004) Rapid physical and biological particle mixing on an intertidal sandflat. J Mar Res 62:67-92 
de Winder B, Staats N, Stal LJ, Paterson DM (1999) Carbohydrate secretion by phototrophic communities in tidal sediments. J Sea Res 42:131-146

Decho AW (1990) Microbial exoploymer secretions in ocean environments: their role(s) in food webs and marine processes. Oceanogr Mar Biol Annu Rev 28:73-153

Easterling DR, Meehl GA, Parmesan C, Changnon SA, Karl TR, Mearns LO (2000) Climate extremes: observations, modeling, and impacts. Science 289:2068-2074

Emery KO (1968) Relict sediments on continental shelves of the world. Am Assoc Pet Geol Bull 52:445-464

> Forster S, Bobertz B, Bohling B (2003) Permeability of sands in the coastal areas of the southern Baltic Sea: Mapping a grain-size related sediment property. Aquat Geochem 9:171-190

Gerbersdorf SU, Jancke T, Westrich B, Paterson DM (2008a) Microbial stabilization of riverine sediments by extracellular polymeric substances. Geobiology 6:57-69

Gerbersdorf SU, Manz W, Paterson DM (2008b) The engineering potential of natural benthic bacterial assemblages in terms of the erosion resistance of sediments. FEMS Microbiol Ecol 66:282-294

Gerbersdorf SU, Bittner R, Lubarsky H, Manz W, Paterson DM (2009a) Microbial assemblages as ecosystem engineers of sediment stability. J Soils Sediments 9:640-652

Gerbersdorf SU, Westrich B, Paterson DM (2009b) Microbial extracellular polymeric substances (EPS) in fresh water sediments. Microb Ecol 58:334-349

Glud RN (2008) Oxygen dynamics of marine sediments. Mar Biol Res 4:243-289

Glud RN, Eyre BD, Patten N (2008) Biogeochemical responses to mass coral spawning at the Great Barrier Reef: Effects on respiration and primary production. Limnol Oceanogr 53:1014-1024

Grant J, Bathmann UV, Mills EL (1986) The interaction between benthic diatom films and sediment transport. Estuar Coast Shelf Sci 23:225-238

Greenwood B, Hale PB (1980) Depth of activity, sediment flux and morphological change in a barred nearshore environment. In: McCann SB (ed) The coastline of Canada. Geol Surv Can Pap 80-10: 89-109

Harrison SJ, Winterbottom SJ, Sheppard C (1999) The potential effects of climate change on the Scottish tourist industry. Tour Manag 20:203-211

Hedtkamp SIC (2005) Shallow subtidal sand: permeability, nutrient dynamics, microphytobenthos and organic matter. PhD dissertation, Christian-Albrechts-Universität, Kiel

Holzbecher E (2002) Advective flow in sediments under the influence of compaction. Hydrolog Sci J 47:641-649

> Huettel M, Gust G (1992) Impact of bioroughness on interfacial solute exchange in permeable sediments. Mar Ecol Prog Ser 89:253-267

Huettel M, Rusch A (2000) Transport and degradation of phytoplankton in permeable sediment. Limnol Oceanogr 45:534-549

Huettel M, Cook P, Janssen F, Lavik G, Middelburg JJ (2007) Transport and degradation of a dinoflagellate bloom in permeable sublittoral sediment. Mar Ecol Prog Ser 340:139-153

> Incera M, Cividanes SP, Lastra M, López J (2003) Temporal and spatial variability of sedimentary organic matter in sandy beaches on the northwest coast of the Iberian Peninsula. Estuar Coast Shelf Sci 58:55-61

> Janssen F, Huettel M, Witte U (2005) Pore-water advection and solute fluxes in permeable marine sediments (II): Benthic respiration at three sandy sites with different permeabilities (German Bight, North Sea). Limnol Oceanogr 50:779-792

Klute A, Dirksen C (1986) Hydraulic conductivity and diffusivity: laboratory methods. In: Klute A. (ed) Methods of soil analysis. Part 1. Argon 9. ASA and SASSA, Madison, WI, p 687-734

> Krembs C, Eicken H, Deming JW (2011) Exopolymer alteration of physical properties of sea ice and implications for ice habitability and biogeochemistry in a warmer Arctic. Proc Natl Acad Sci USA 108:3653-3658

Krumbein WC, Monk GD (1942) Permeability as a function of the size parameters of unconsolidated sand. Petroleum Technology, AIME Tech Publ No. 1942, 5(4):1-11

Leach JH (1971) Hydrology of the Ythan Estuary with reference to the distribution of major nutrients and detritus. J Mar Biol Assoc UK 51:137-157

Meadows PS, Meadows A (1991) The geotechnical and geochemical implications of bioturbidation in marine sedimentary ecosystems. Symp Zool Soc Lond 63: 157-181

> Middelburg JJ, Barranguet C, Boschker HTS, Herman PMJ, Moens T, Heip CHR (2000) The fate of intertidal microphytobenthos carbon: an in situ ${ }^{13} \mathrm{C}$-labeling study. Limnol Oceanogr 45:1224-1234

Mukai T, Takimoto K, Kohno T, Okada M (2000) Ultrafiltration behavior of extracellular and metabolic products in activated sludge system with UF separation process. Wat Res 34:902-908

> Paterson DM (1995) Biogenic structure of early sediment fabric visualized by low-temperature scanning electron microscopy. J Geol Soc London 152:131-140

> Perkins RG, Davidson IR, Paterson DM, Sun H, Watson J, Player MA (2006) Low-temperature SEM imaging of polymer structure in engineered and natural sediments and the implications regarding stability. Geoderma 134: $48-55$

> Pilditch CA, Miller DC (2006) Phytoplankton deposition to permeable sediments under oscillatory flow: effects of ripple geometry and resuspension. Cont Shelf Res 26: 1806-1825

Probert K (1984) Disturbance, sediment stability, and trophic structure of soft-bottom communities. J Mar Res 42: 893-921

Rehg KJ, Packman AI, Ren J (2005) Effects of suspended sediment characteristics and bed sediment transport on streambed clogging. Hydrol Process 19:413-427

> Rocha C, Forster S, Koning E, Epping E (2005) High-resolution permeability determination and two-dimensional porewater flow in sandy sediment. Limnol Oceanogr Methods 3:10-23

Rusch A, Forster S, Huettel M (2001) Bacteria, diatoms and detritus in an intertidal sandflat subject to advective transport across the water-sediment interface. Biogeochemistry 55:1-27

> Shepherd RG (1989) Correlations of permeability and grain size. Ground Water 27:633-638

Spinelli GA, Giambalvo ER, Fisher AT (2004) Sediment permeability, distribution, and influence on fluxes in oceanic basement. In: Davis EE, Elderfield H (eds) Hydrogeology of the oceanic lithosphere. Cambridge University Press, Cambridge, p 151-188

Stal LJ (2010) Microphytobenthos as a biogeomorphological force in intertidal sediment stabilization. Ecol Eng 36: $236-245$ 
Thullner M (2010) Comparison of bioclogging effects in saturated porous media within one- and two-dimensional flow systems. Ecol Eng 36:176-196

Underwood GJC, Paterson DM (1993) Seasonal changes in diatom biomass, sediment stability and biogenic stabilization in the Severn Estuary. J Mar Biol Assoc UK 73: 871-887

Underwood GJC, Paterson DM (2003) The importance of extracellular carbohydrate production by marine epipelic diatoms. Adv Bot Res 40:183-240

Underwood GJC, Paterson DM, Parkes RJ (1995) The measurement of microbial carbohydrate exopolymers from intertidal sediments. Limnol Oceanogr 40:1243-1253

Volkenborn N, Hedtkamp SIC, Van Beusekom JEE, Reise K (2007) Effects of bioturbation and bioirrigation by lugworms (Arenicola marina) on physical and chemical sediment properties and implications for intertidal habitat succession. Estuar Coast Shelf Sci 74:331-343

Waldbusser GG, Marinelli RL (2009) Evidence of infaunal effects on porewater advection and biogeochemistry in

Editorial responsibility: Paul Snelgrove, St. John's, Newfoundland, Canada permeable sediments: A proposed infaunal functional group framework. J Mar Res 67:503-532

> Wilson AM, Huettel M, Klein S (2008) Grain size and depositional environment as predictors of permeability in coastal marine sands. Estuar Coast Shelf Sci 80:193-199

Wiltshire KH, Blackburn J, Paterson DM (1997) The Cryolander; a new method for fine-scale in situ sampling of intertidal surface sediments. J Sediment Res 67: 977-981

> Wood SN (2004) Stable and efficient multiple smoothing parameter estimation for generalized additive models. J Am Stat Assoc 99:673-686

Wood SN (2006) Generalized additive models. An introduction in R. Chapman \& Hall/CRC, Boca Raton, FL

Wood SN (2008) Fast stable direct fitting and smoothness selection for generalized additive models. J R Stat Soc, B 70:495-518

Zuur AF, Ieno E, Walker NJ, Saveliev AA, Smith GM (2009) Mixed effects models and extensions in ecology with R. Springer, New York

Submitted: February 17, 2011; Accepted: August 30, 2011

Proofs received from author(s): November 3, 2011 